\title{
Effect of Climate Change on Agricultural Operations in Dharwad District of Karnataka, India
}

\author{
Huchhappa Gondali* and Dipak Kumar Bose
}

Department of Agricultural Extension \& Communication, Sam Higginbottom University of Agriculture, Technology and Sciences, Naini, Allahabad-211 007, U.P., India

*Corresponding author

\section{Keywords \\ Effect, Climate \\ Change, \\ Agricultural \\ operation \\ Article Info \\ Accepted: \\ 15 January 2019 \\ Available Online: \\ 10 February 2019}

\section{A B S T R A C T}

Climate is the primary determinant of agricultural productivity. Climate change effects agricultural operations in a number of ways, including through changes in average temperatures, rainfall, and climate extremes. Concern over the potential effects of longterm climatic change on agriculture has motivated a substantial body of research over the past decade. The present study was conducted in Dharwad districts of Karnataka state during 2016-17. Descriptive research design was followed to assess the effect of climate change on agricultural operations with a sample of 120 respondents selected randomly. The findings inferred that cent percent respondents noticed negative impacts with regard to crops grown, insect pest infestation and overall health of the crop, negative impacts $(97.50 \%)$ as expressed by almost all the respondents about time of application of chemical fertilizer, intercultural operation and pesticide use. Among the remaining practices, more than 90 per cent of the respondents mentioned negative impact for 8 practices such as Disease infestation (96.97\%), cropping pattern (96.67\%), grain yield quantity (95.83\%), Harvesting (93.33\%), Grain yield quality (92.50\%), sowing time (91.67\%), Straw yield obtained $(91.67 \%)$ and intensity of weeds $(90.00 \%)$. It was also found that majority of the respondents $(86.67 \%)$ observed negative impacts for soil fertility and use of chemical fertilizer, no effect of seed rate $(86.67 \%)$, seed treatment $(83.33 \%)$, spacing $(80.00 \%)$ and FYM application $(73.33 \%)$.

\section{Introduction}

Agriculture is one of the sectors most affected by on-going climate change. The wide range of literature on this subject demonstrates that damages caused by climate change can be relevant to both cropping and livestock activities (IPCC, 1990; Adams et al., 1998). The on-going effects of climate change require the individuation of mitigation policies to reduce greenhouse gas emissions and identify appropriated adaptation strategies that aim to contain agricultural losses both in market goods and environmental services (such as protection of biodiversity, water management, landscape preservation and so on). These strategies can easily be identified and applied if the economic effects of climate 
change on agriculture are assessed. However, creating models that are able to assess these effects accurately can present difficulties for several reasons. The first is data availability: while data are frequently available, they are often not disaggregated on the necessary temporal and/or spatial scales. Another reason is that research about the effects of climate change involves multidisciplinary skills and competencies because analyses of the effects of climate change involve many factors such as the consideration of (Bosello and Zang, 2005): Climate change will have a significant effect on the rural landscape and the equilibrium of agrarian and forest ecosystems (Walker and Steffen, 1997; Bruijnzeel, 2004). In fact, climate change can affect different agricultural dimensions, causing losses in productivity, profitability and employment. Food security is clearly threatened by climate change (Sanchez, 2000; Siwar et al., 2013), due to the instability of crop production, and induced changes in markets, food prices and supply chain infrastructure. Moreover, because of the multiple socio-economic and bio-physical factors affecting food systems and, consequently food security, the capacity to adapt food systems to reduce their vulnerability to climate change is not uniform from a spatial point of view (Gregory et al., 2005). Climate change although a global phenomena but the real cost of it is being paid by the poorest of the poor like farmers and agriculture labour. There are number of studies made on climate change both at national and international level to understand the effect of climate change on agriculture However, very limited studies have been done to understand farmer's perspectives and experience of climate change in crop cultivation. It is felt very essential to understand their perspectives also, so that better holistic policy decision could be made. Several efforts has been done by the different extension functionaries to minimize the effects of climate change on agriculture but recent report should that the result one not up to the marks as it was expected.

\section{Materials and Methods}

The present investigation was conducted in Taluk Kundagol of Dharwad district which was selected purposively based on depending upon extent of climate variation. The study covered 12 villages and 120 respondents who had more than 15 years of farming experience selected randomly. Data were collected by using pre-tested interview schedule. The data on socio-economic aspects like education, age, family type, land holding, occupation, income, mass media exposure were collected. The information was also gathered through focused group discussion and observation methods. The collected data were coded, tabulated, classified and analysed by both descriptive and inferential statistics to draw the conclusion.

\section{Results and Discussion}

\section{Effects of climate change on agricultural operations as perceived by the respondents}

Farmers shared some experience of changing climate and its impact on agricultural operations (Table 1). Responses were elicited for twenty eight farm practices. Majority of the respondents expressed that climate change has resulted in negative impacts on most of the farm practices. For some of the farm practices, no effects were observed by the respondents. Majority of the respondent $(100 \%)$ crops grown, insect pest infestation (100\%), overall health of the crop (100\%), three practices in which all the respondents noticed negative impacts. Closely followed by these were the practices, with negative impacts as expressed by almost all the respondents Time of application of chemical fertilizer $(97.50 \%)$, no effect $(2.50 \%)$. Intercultural operation $(97.50 \%)$, no effect 
$(2.50 \%)$ and Pesticide use (97.50\%), no effect $(2.50 \%)$. mong the remaining practices, more than 90 per cent of the respondents mentioned negative impact for 8 practices.

Were Cropping pattern (96.67), no effect $(3.33 \%)$. disease infestation $(96.97 \%)$, no effect $(3.33 \%)$. Grain Yield quantity $(95.83 \%)$, no effect $(4.17 \%)$ harvesting $(93.33 \%)$, no effect $(6.67 \%)$. Grain yield quality $(92.50 \%)$, no effect $(7.50 \%)$. Sowing time $(91.67 \%)$ no effect $(8.33 \%)$. Straw yield obtained (91.67\%), no effect $(8.33 \%)$. And Intensity of weeds $(90.00 \%)$, no effect $(10.00 \%)$. Large majority of the respondents observed negative impacts for Soil fertility $(86.67 \%)$, no effect $(13.33 \%)$. Use of chemical fertilizer (86.67\%), no effect $(13.33 \%)$. Shelf life of the crop (80.83\%), no effect $(19.17 \%)$, Taste of the produce $(80.00$ $\%)$, no effect $(20.00 \%)$. No. of Irrigation $(73.33 \%)$, no effect $(26.67 \%)$. Land preparation $(66.67 \%)$, no effect $(33.33 \%)$. Storage pest and diseases $(66.00 \%)$, no effect $(33.33 \%)$.

Variety selection $(60.00 \%)$, no effect $(40.00$ $\%)$. Storage duration $(55.00 \%)$, no effect (45.00\%). And Market price (53.33\%), no effect $(46.67 \%)$ received mixed responses from the respondents as almost half of them mentioning negative and the rest mentioned no impacts. However majority respondents mentioned that climate change had no effect on seed rate used $(86.67 \%)$, negative $(33.33$ $\%)$. seed treatment practices $(83.33 \%)$, Negative (16.67\%).spacing (80.00), negative $(20.00 \%)$. And FYM application (73.33 \%), negative $(26.67 \%)$.

Despite technological advances, such as improved varieties, genetically modified organisms, and irrigation systems, weather is still a key factor in agricultural productivity, as well as soil properties and natural communities. The effect of climate on agriculture is related to variabilities in local climates rather than in global climate patterns. Hence climate effects on different crop production practices as perceived by the respondents were studied.

Application of fertiliser in relation to soil and air temperatures is important because these conditions affect plant growth and hence nutrient use. Fertiliser application should be timed to achieve maximum plant uptake, thereby reducing losses of nutrient to the environment. Consider also the amount of rainfall and/or irrigation experienced or expected. Change in climate, however, brought shift in time of application of fertiliser resulting in perceived negative impact. Robinson (1998) also reported similar results. Farmers expressed that application of fertiliser in high rainfall period as experienced by them in the last two decades resulted in leaching of nutrients applied and improper dissolution during drought period leading to the suffocation and burning impacts. Soil condition is necessary to take up intercultural operations either by bullocks or tractor.

Farmers perceived negative impact on weed growth as a result of increased crop weed competition compared to earlier. A very important point to consider is that weeds would undergo the same acceleration of cycle as cultivated crops, and would also benefit from carbonaceous fertilization. Since most weeds are C3 plants, they are likely to compete even more than now against $\mathrm{C} 4$ crops such as corn. An increase in rainfall in study areas would lead to an increase of atmospheric humidity and the duration of the wet seasons. Combined with higher temperatures, these could favor the development of insects and diseases like bugs and thribs (hard bodied), smuts, powdery mildew and downey mildew. Similarly, because of higher temperatures and humidity, there could be an increased pressure from insects and disease vectors. 
Table.1 Effects of climate change on agricultural operations as perceived by farmers in the last two decades

\begin{tabular}{|c|c|c|c|}
\hline \multirow[t]{2}{*}{ Sl. No. } & \multirow[t]{2}{*}{ Particulars } & \multicolumn{2}{|c|}{ Effect of climate change } \\
\hline & & $\begin{array}{c}\text { Negative } \\
\mathbf{F}(\%)\end{array}$ & $\begin{array}{c}\text { No effect } \\
F(\%)\end{array}$ \\
\hline 1 & Soil fertility & $\begin{array}{c}104 \\
(86.67)\end{array}$ & $\begin{array}{c}16 \\
(13.33)\end{array}$ \\
\hline 2 & Crops grown & $\begin{array}{c}120 \\
(100.00)\end{array}$ & $\begin{array}{c}0 \\
(0.00)\end{array}$ \\
\hline 3 & Cropping pattern & $\begin{array}{c}116 \\
(96.67)\end{array}$ & $\begin{array}{c}4 \\
(3.33)\end{array}$ \\
\hline 4 & Variety selection & $\begin{array}{c}72 \\
(60.00)\end{array}$ & $\begin{array}{c}48 \\
(40.00)\end{array}$ \\
\hline 5 & Land preparation & $\begin{array}{c}80 \\
(66.67)\end{array}$ & $\begin{array}{c}40 \\
(33.33)\end{array}$ \\
\hline 6 & Sowing time & $\begin{array}{c}110 \\
(91.67)\end{array}$ & $\begin{array}{c}10 \\
(8.33)\end{array}$ \\
\hline 7 & Spacing & $\begin{array}{c}24 \\
(20.00)\end{array}$ & $\begin{array}{c}96 \\
(80.00)\end{array}$ \\
\hline 8 & Seed rate & $\begin{array}{c}16 \\
(13.33)\end{array}$ & $\begin{array}{c}104 \\
(86.67)\end{array}$ \\
\hline 9 & Seed treatment & $\begin{array}{c}20 \\
(16.67)\end{array}$ & $\begin{array}{c}100 \\
(83.33)\end{array}$ \\
\hline 10 & FYM application & $\begin{array}{c}32 \\
(26.67)\end{array}$ & $\begin{array}{c}88 \\
(73.33)\end{array}$ \\
\hline 11 & Use of chemical fertilizer & $\begin{array}{c}104 \\
(86.67)\end{array}$ & $\begin{array}{c}16 \\
(13.33)\end{array}$ \\
\hline 12 & $\begin{array}{l}\text { Time of application of chemical } \\
\text { fertilizer }\end{array}$ & $\begin{array}{c}117 \\
(97.50)\end{array}$ & $\begin{array}{c}3 \\
(2.50)\end{array}$ \\
\hline 13 & Intercultural operation & $\begin{array}{c}117 \\
(97.50)\end{array}$ & $\begin{array}{c}3 \\
(2.50)\end{array}$ \\
\hline 14 & Intensity of weeds & $\begin{array}{c}108 \\
(90.00)\end{array}$ & $\begin{array}{c}12 \\
(10.00)\end{array}$ \\
\hline 15 & Insect Pest infestation & $\begin{array}{c}120 \\
(100.00)\end{array}$ & $\begin{array}{c}0 \\
(0.00)\end{array}$ \\
\hline 16 & Disease infestation & $\begin{array}{c}116 \\
(96.97)\end{array}$ & $\begin{array}{c}4 \\
(3.33)\end{array}$ \\
\hline 17 & Pesticide use & $\begin{array}{c}117 \\
(97.50)\end{array}$ & $\begin{array}{c}3 \\
(2.50)\end{array}$ \\
\hline 18 & No. of Irrigation & $\begin{array}{c}88 \\
(73.33)\end{array}$ & $\begin{array}{c}32 \\
(26.67)\end{array}$ \\
\hline 19 & Harvesting & 112 & 8 \\
\hline
\end{tabular}




\begin{tabular}{|c|l|c|c|}
\hline & & $(93.33)$ & $(6.67)$ \\
\hline $\mathbf{2 0}$ & Grain Yield quantity & 115 & 5 \\
& & $(95.83)$ & $(4.17)$ \\
\hline $\mathbf{2 1}$ & Grain yield quality & $(92.50)$ & 9 \\
& & 110 & $(7.50)$ \\
\hline $\mathbf{2 2}$ & Straw yield obtained & $(91.67)$ & 10 \\
& & 66 & $(8.33)$ \\
\hline $\mathbf{2 3}$ & Storage duration & $(55.00)$ & $(45.00)$ \\
\hline $\mathbf{2 4}$ & Market price & 64 & 56 \\
& & $(53.33)$ & $(46.67)$ \\
\hline $\mathbf{2 5}$ & Overall health of the crop & 120 & 0 \\
& & $(100.00)$ & $(0.00)$ \\
\hline $\mathbf{2 6}$ & Shelf life of the crop & 97 & 23 \\
& & $(80.83)$ & $(19.17)$ \\
\hline $\mathbf{2 7}$ & Storage pest and diseases & 80 & 40 \\
& & $(66.67)$ & $(33.33)$ \\
\hline $\mathbf{2 8}$ & Taste of the produce & 96 & 24 \\
& & $(80.00)$ & $(20.00)$ \\
\hline
\end{tabular}

$\mathrm{F}=$ Frequency $\quad \%=$ Percentage

Regarding quantity of grain yield farmers were observing fluctuation in year to year yield due to regular vagaries in climate. This is in concurrence with the findings expressed by Sinha and Swaminathan (1991) and Rao and Sinha (1994). More than three fourth of the respondents expressed negative changes in number of irrigation withstanding water shortages of crops by evaporation and evapo transpiration there is need to aggregate intensification in number of irrigations. Farmers encountering intensification in number of irrigation as a result of increased scorching sunny hours and temperature leading to more water loss in all the stages, These are the practices which might have affected due to climate change indirectly as farmers are growing hybrids and dwarf varieties which influence the straw yield and taste of the produce. Farmers observing fluctuation in market price as an indirect impact of climate change, year to year vagaries in climate leading to fluctuation in production level. This is leading to fluctuation in prices.
Neutral effect of climate change was observed for seed rate, seed treatment, with this regard farmers not aware about technical relevance of the practice and farmers were not giving precise importance to the above practice, so they are lack ability to observe any effects. FYM application farmers observed improper decomposition thereby crop is affected by spreading of weeds, pests and diseases through FYM, this is the case observing in the study area because insufficient moisture (rainfall) for decomposition and late onset of rain fall leading to germination /proliferation of weeds and pests in the established crop field. This leading farmer not to practices stale bed for submergence of weeds, pests and disease infected soil what farmers practiced in case of early onset of rainfall. The above finding is in concurrence with the findings of Gajendra (2011).

It was concluded that climate is the primary determinant of agricultural operations as well as agricultural productivity which directly impact on food production across the globe. 
Agriculture sector is the most sensitive sector to the climate changes because the climate of a region/country determines the nature and agricultural operations of crop. Increase in the mean seasonal temperature can reduce the duration of many crops and hence reduce final yield. Coping with the effects of climate change on agriculture will require careful management of resources like soil, water and biodiversity. To minimize the negative effects of climate change on Agricultural operations Government will need to form proper act and extension strategies at the global, regional, national and local levels.

\section{References}

Adams RM, Hurd BH, Lenhart S, Leary N (1998). Effects of global climate change on agriculture: An interpretative review. Climate. Res. 11(1): 19-30.

Ahmad J Alam D and Hassen S. (2013) Impact of Climate Change on Agriculture \& Food Security in India, Pp. 131-136.

Bosello F, Zang J (2005). Assessing Climate Change Impacts: Agriculture, FEEM Nota di Lavoro 94. 2005, Fondazione
Eni Enrico Mattei. Bruijnzeel LA (2004).

Bruijnzeel LA (2004). Hydrological functions of tropical forests: Not seeing the soil for the trees. Agric. Ecosystem. Environ. 104(1):185-228.

Gregory PJ, Ingram JSI, Brklacich M (2005). Climate change and food security. Philos. Trans. R Soc. London B Biol. Sci. 360(1463): 2139-2148.

Intergovernmental Panel on Climate Change (1990): IPCC First Assessment Report 1990 (FAR).

Sanchez PA (2000). Linking climate change research with food security and poverty reduction in the tropics Agriculture. Econ. Environ. 82(1-3):371-383.

Siwar C, Ahmed F, Begum RA (2013). Climate change, agriculture and food security issues: Malaysian perspective. J. Food Agric. Environ. 11(2):11181123.

Walker B, Steffen W (1997). An overview of the implications of global change for natural and managed terrestrial ecosystems. Conservation Ecology, Vol. 1, No. 2, 1997, pp. 2-17.

\section{How to cite this article:}

Huchhappa Gondali and Dipak Kumar Bose. 2019. Effect of Climate Change on Agricultural Operations in Dharwad District of Karnataka, India. Int.J.Curr.Microbiol.App.Sci. 8(03): 19041909. doi: https://doi.org/10.20546/ijcmas.2019.803.226 